\title{
Simultaneous identification of viruses and SARS-CoV-2 variants with programmable DNA nanobait
}

Filip Bošković ${ }^{1}$, Jinbo Zhu ${ }^{1}$, Ran Tivony ${ }^{1}$, Alexander Ohmann ${ }^{1}$, Kaikai Chen ${ }^{1}$, Mohammed F. Alawami ${ }^{1}$, Milan Đorđević ${ }^{1}$, Niklas Ermann¹, Joana Pereira Dias ${ }^{2,3}$, Michael Fairhead ${ }^{4}$, Mark Howarth ${ }^{4}$, Stephen Baker $^{2,3}$, Ulrich F. Keyser ${ }^{1, *}$

${ }^{1}$ Cavendish Laboratory, University of Cambridge, JJ Thomson Avenue, Cambridge, CB3 OHE, UK

${ }^{2}$ University of Cambridge School of Clinical Medicine, Cambridge Biomedical Campus, Hills Road, Cambridge, CB2 0SP, UK

${ }^{3}$ Department of Medicine, University of Cambridge School of Clinical Medicine, Cambridge Biomedical Campus, Hills Road, Cambridge, CB2 0QQ, UK

${ }^{4}$ Department of Biochemistry, University of Oxford, South Parks Road, Oxford, OX1 3QU, UK * corresponding author 


\begin{abstract}
Respiratory infections are the major cause of death from infectious disease worldwide. The clinical presentation of many respiratory viruses is indistinguishable; therefore, diagnostic approaches that can identify multiple pathogens are essential for patient management. We aimed to address this challenge with self-assembled DNA nanobait that can simultaneously identify multiple short RNA targets. The nanobait approach relies on specific target selection via toehold-mediated strand displacement and rapid read-out via nanopore sensing. Here, we show this platform can concurrently identify several common respiratory viruses, detecting a panel of short targets of viral nucleic acids from SARS-CoV-2, respiratory syncytial virus (RSV), rhinovirus, influenza, and parainfluenza. Our nanobait could be reprogrammed to discriminate viral variants, and we identified several key SARS-CoV-2 variants with single-nucleotide resolution. We increased assay specificity with bespoke nanobait that could identify numerous short RNA targets in the same viral sample in a complex background of the human transcriptome. Notably, we found that the sequence position in the viral RNA secondary structure is critical for nanobait design. Lastly, we show that nanobait could discriminate between samples extracted from oropharyngeal swabs from negative and positive SARS-CoV-2 patients using programmable target cleavage without preamplification. Our system allows for multiplexed identification of native RNA molecules, providing a new scalable approach for diagnostics of multiple respiratory viruses in a single assay.
\end{abstract}




\section{Introduction}

The diagnosis of infectious diseases plays a vital role in determining appropriate patient treatment ${ }^{1}$. Respiratory tract infections are the major cause of death from infectious diseases globally ${ }^{2,3}$. Many respiratory viruses induce comparable symptoms and cannot be differentiated clinically, making the identification of appropriate treatment challenging. It is estimated that $65 \%$ of infection-associated cases of pneumonia are potentially misdiagnosed, with $95 \%$ of these cases erroneously receiving antimicrobials ${ }^{4}$. The ongoing COVID-19 pandemic further highlights another unmet diagnostic need: the routine identification and screening of viral variants as they arise ${ }^{5}$.

Currently, viral diagnostics rely on quantitative reverse transcription-polymerase chain reaction (qRTPCR), followed by genome sequencing to detect viral variants ${ }^{5,6}$. PCR-based diagnostic methods provide a sensitive approach for detecting viral nucleic acids in complex biological samples but suffer from limited multiplexing capabilities ${ }^{7}$. There is a need for robust diagnostic methods that can simultaneously detect multiple respiratory viruses and variants in limited sample volume, which can be quickly reconfigured to detect additional variants as they arise. Newer nucleic acid detection methods, such as nanopore sensing, which can distinguish multiple nucleic acid species ${ }^{8-11}$ with a unique signature for each designed DNA nanostructure may be an alternative approach for multiplexed biosensing ${ }^{19,29,30}$. Various groups have shown that nanopore sensing after viral nucleic acid enrichment or amplification may be a suitable platform to challenge these diagnostics ${ }^{10,12,13}$.

Here, aiming to solve many of the limitations for diagnostic multiplexing, we developed an innovative method that employs bespoke nanobait for the simultaneous identification of multiple respiratory viruses and variants ${ }^{14}$. We employed programmable viral RNA cutting with RNase $\mathrm{H}$ to remove short RNA targets that uniquely identifies the virus. The resultant RNA target is captured by nanobait, which is detected instantaneously by nanopore sensing, without reverse transcription, pre-amplification, or purification. By multiplexing several targets from the same virus in samples containing human RNA, we 
show that our method can increase specificity and throughput compared to existing platforms and paves the way for amplification-free RNA identification and diagnostics.

\section{Methods}

\section{Patient sample collection}

Patient samples were collected by swabbing the back of the throat (oropharyngeal swab) of patients as previously described ${ }^{15}$. The samples were collected from patients with the COVID-19-like clinical picture and were tested with the qRT-PCR after nucleic acid extraction. Briefly, after collection, swabs were placed into a labeled sample tube containing lysis buffer (4 M guanidine thiocyanate, $25 \mathrm{mM}$ Tris- $\mathrm{HCl}$, $0.5 \% \beta$-mercaptoethanol, and MS2 RNA (Roche; $200 \mathrm{ng} / \mu \mathrm{l})$ ). The tube was gently agitated to ensure the even distribution of lysis buffer. The safety steps have been previously described and performed in a certified CL2 laboratory ${ }^{15}$.

\section{Nucleic acid extraction}

Total nucleic acid was extracted using spin column-based systems and as employed by standardized qRTPCR testing ${ }^{15}$. The internal amplification control (MS2 $\left(\sim 6 \times 10^{4}\right.$ PFU/ml) per $10 \mathrm{ml}$ of lysis buffer) was added in the top-up lysis buffer ( $25 \mu 1$ per $10 \mathrm{ml}$ of lysis buffer). The sample was eluted in $100 \mu 1$ of nuclease-free water ( $\mathrm{nfH}_{2} \mathrm{O}$, Invitrogen) and left to stand for 1 minute prior to centrifugation for 1 minute at 15,000 rpm in a benchtop microfuge. Eluted samples were directly subjected to qRT-PCR. The remaining nucleic acid extracts were stored at $-80{ }^{\circ} \mathrm{C}$ and further used for nanobait-nanopore sensing. Quantitative reverse-transcription polymerase chain reaction (qRT-PCR) for SARS-CoV-2

SARS-CoV-2 detection was performed as previously described ${ }^{15}$. Per reaction, the master mix contained $12.5 \mu \mathrm{l}$ of $2 \times$ Luna Universal Probe One-Step reaction mix, $0.5 \mu \mathrm{l}$ of $20 \mu \mathrm{M}$ Wu forward primer (5'ATGGGTTGGGATTATCCTAAATGTGA-3'), $0.5 \mu 1$ of $20 \mu \mathrm{M}$ Wu reverse primer (5'- 
medRxiv preprint doi: https://doi.org/10.1101/2021.11.05.21265890; this version posted November 10, 2021. The copyright holder for this

It is made available under a CC-BY-NC-ND 4.0 International license .

GCAGTTGTGGCATCTCCTGATGAG-3'), $0.3 \mu$ l of $10 \mu \mathrm{M}$ MGB Probe 3 FAM (5'-

ATGCTTAGAATTATGGCCTCAC-3'), $0.5 \mu 1$ of $10 \mu \mathrm{M}$ of internal control forward primer for MS2 RNA, $0.5 \mu 1$ of $10 \mu \mathrm{M}$ internal control reverse primer for MS2 RNA, $0.3 \mu 1$ of $10 \mu \mathrm{M}$ internal probe

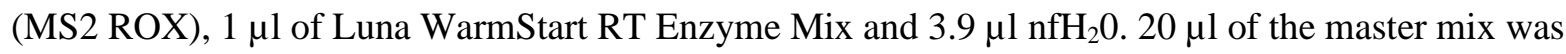
aliquoted into each well of a 96-well plate and then combined with $5 \mu 1$ of each extract. The MS2 internal extraction and amplification control that underwent the full extraction protocol was included as the negative extraction control in a minimum of two wells on the qRT-PCR plate. To determine potential

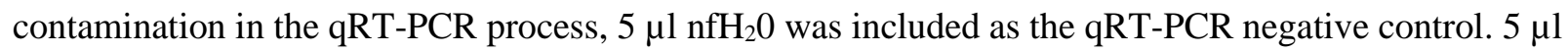
of spiked SARS-CoV-2 template plasmid was included in a single well as the qRT-PCR positive control. After adding $5 \mu \mathrm{l}$ of each sample to its designated well, the plate was sealed with an optically clear plastic seal. The plate was centrifuged for $1 \mathrm{~min}$ at $1,000 \mathrm{rpm}$ at $4{ }^{\circ} \mathrm{C}$ and then inserted in the qRT-PCR machine (QuantStudio, Thermo Fisher Scientific) and the run was parametrized. Signals for fluorescein (FAM) and carboxyrhodamine (ROX) were acquired. ROX was used to detect the internal MS2 control and FAM was used to detect SARS-CoV-2 RNA. The assay was performed for 2 minutes at $25{ }^{\circ} \mathrm{C}, 15$ minutes at 50 ${ }^{\circ} \mathrm{C}$ (for the reverse-transcriptase), 2 minutes at $90{ }^{\circ} \mathrm{C}$, before 45 cycles of $95^{\circ} \mathrm{C}$ for 3 seconds followed by $60{ }^{\circ} \mathrm{C}$ for 30 seconds. Results were determined by confirmation of the correct positive controls (amplification of the plasmid), the extraction and amplification controls of all samples (ROX channel), no amplification in the negative controls, and consistent mean values of controls. SARS-CoV-2 positivity was confirmed by amplification in the FAM channel with an appropriate sigmoidal curve with a cycle threshold (CT) value of $\leq 36$. The CT values of MS2 and MGB probe 3 were maintained to track the quality and reproducibility of the assay ${ }^{16}$.

\section{Programmable RNase H cutting for nanobait}

For nanopore sensing, nucleic acid extracts (patient samples) or MS2 viral RNA were used further for the detection with nanobait. Firstly, we mixed guide oligos with the sample and heated it to $70{ }^{\circ} \mathrm{C}$ for 5 
minutes. RNase $\mathrm{H}$ (5,000 units/ml, NEB) was added, mixed, and heated for 20 minutes at $37^{\circ} \mathrm{C}$ to allow the enzyme to cut RNA in the DNA : RNA hybrid that effectively releases target RNA.

\section{Viral target sequence properties for nanobait}

For the DNA nanobait designs, target sequences were selected to be in the conserved regions of a viral genome and had 40-60\% GC content to form a stable duplex. We tested all sequences for potential undesirable highly stable intramolecular interactions or homodimers using Nupack software ${ }^{17}$. Then we performed a cross-reactivity check between multiple sites employed in each experiment ${ }^{17}$.

\section{Preparation of DNA flower for nanobait}

We designed a DNA flower as another label for SARS-CoV-2 RNA detection from the patient samples. Three DNA flowers specific for each SARS-CoV-2 target (7-way junctions, 7WJa, 7WJb, and 7WJc) were prepared separately. Taking $7 \mathrm{WJc}$ as an example, $4 \mu \mathrm{M}$ DNA strand $\mathrm{J} 1, \mathrm{~J} 2$, J3, and J4c (Supplementary Table S1) were mixed together in TM buffer (10 mM Tris- $\mathrm{HCl}, 10 \mathrm{mM} \mathrm{MgCl} 2, \mathrm{pH} 8.0$ ) and heated to $90{ }^{\circ} \mathrm{C}$ for $5 \mathrm{~min}$, then cooled down to $65^{\circ} \mathrm{C}$ for $15 \mathrm{~min}, 45^{\circ} \mathrm{C}$ for $15 \mathrm{~min}, 37^{\circ} \mathrm{C}$ for $20 \mathrm{~min}$, $25{ }^{\circ} \mathrm{C}$ for $20 \mathrm{~min}$ and finally $4{ }^{\circ} \mathrm{C}$ for $20 \mathrm{~min}$. Strand $\mathrm{J} 4 \mathrm{c}$ was substituted by J4b to prepare $7 \mathrm{WJb}$. For 7WJa, to avoid self-folding at site 43 on the nanobait, J1, J2, J3 J4a, and C43 were mixed together before annealing.

\section{Self-assembly of DNA nanobait}

DNA nanobait was assembled by mixing linearized single-stranded M13 DNA (m13mp18, 7249 nt, Guild Biosciences, $100 \mathrm{nM}$ ) with short complementary oligonucleotides ${ }^{18}$ some of those harboring reference structures, capture strands, and by adding partially complementary strands that were 3'-biotinylated for toehold-mediated strand displacement reaction. The mix contained $20 \mathrm{nM}$ of linearized M13 DNA, $60 \mathrm{nM}$ of oligonucleotides, 3'-biotinylated strands in the concentration of $180 \mathrm{nM}, 10 \mathrm{mM} \mathrm{MgCl}_{2}$, and $1 \times \mathrm{TE}$ (10 mM Tris-HCl, $1 \mathrm{mM}$ EDTA, pH 8.0). It was mixed by pipetting and spun down before heating to 70 ${ }^{\circ} \mathrm{C}$ for $30 \mathrm{~s}$ and cooled down over $45 \mathrm{~min}$ to ambient temperature. Excess oligonucleotides were removed 
medRxiv preprint doi: https://doi.org/10.1101/2021.11.05.21265890; this version posted November 10, 2021. The copyright holder for this preprint (which was not certified by peer review) is the author/funder, who has granted medRxiv a license to display the preprint in perpetuity.

It is made available under a CC-BY-NC-ND 4.0 International license .

using Amicon ${ }^{\circledR}$ ultra $0.5 \mathrm{~mL}$ centrifugal filters with 100 kilodalton $(\mathrm{kDa})$ cutoff with the washing buffer (10 $\mathrm{mM}$ Tris- $\mathrm{HCl} \mathrm{pH} 8.0,0.5 \mathrm{mM} \mathrm{MgCl}_{2}$ ). If DNA flowers were employed as a label, the partially complementary strands that carry it were incubated in $10 \mathrm{mM} \mathrm{MgCl} 2$ for $2 \mathrm{~h}$ at ambient temperature, and subsequently, Amicon filtration was performed as described above. The asymmetry of the nanobait design allows for unambiguous identification of the binding sites.

\section{Nanopore readout of DNA nanobait}

Nanobait was mixed with a sample (nucleic acid extract or purified viral targets) in $10 \mathrm{mM} \mathrm{MgCl} 2$ and $100 \mathrm{mM} \mathrm{NaCl}$. The mixture $(5 \mu \mathrm{L})$ was incubated at room temperature $(\sim 10 \mathrm{~min})$ until prepared for nanopore measurement. We have used human total universal RNA (htRNA, Invitrogen) as a background where indicated, to show that there are no nonspecific signals induced by human native RNAs. For nanopore measurement, the sample was diluted to $<0.5 \mathrm{nM}$ nanobait (for purified viral targets) or $4.7 \mu \mathrm{L}$ of RNase $\mathrm{H}$ cut patient sample was mixed with $0.3 \mu \mathrm{L}$ of monovalent streptavidin (SAeID3) ${ }^{19}(1 \mu \mathrm{M}), 5$

$\mu \mathrm{L}$ of $\mathrm{LiCl}(4 \mathrm{M})$, and $5 \mu \mathrm{L}$ of $\mathrm{LiCl}(8 \mathrm{M})$. We have fabricated $14 \pm 3 \mathrm{~nm}$ (mean \pm s.d.) nanopores ${ }^{18}$ using quartz glass capillaries with $0.5 \mathrm{~mm}$ outer diameter and 0.2 inner diameter (Sutter Instrument) by laserassisted puller P-2000 (Sutter Instrument). The mix was pipetted in a nanopore PDMS (polydimethylsiloxane) chip, and all measurements were performed at a constant voltage of $600 \mathrm{mV}$. Nanopore measurement details are shown in Supplementary Table S29.

\section{Real-time nanopore data analysis}

Nanopore data analysis was explained in Supplementary section S13. Briefly, nanobait events were filtered out of raw ionic current traces, then the detection region was determined, and information of the spike's presence at each specific site was extracted. The displacement efficiency was calculated as a difference between a no target control and a measurement for each site (fifty nanobait events for each of three nanopore recordings). We verified that the convolutional neural network QuipuNet ${ }^{20}$ was capable of real-time analysis of nanopore data following the described procedure. 
medRxiv preprint doi: https://doi.org/10.1101/2021.11.05.21265890; this version posted November 10, 2021. The copyright holder for this preprint (which was not certified by peer review) is the author/funder, who has granted medRxiv a license to display the preprint in perpetuity.

It is made available under a CC-BY-NC-ND 4.0 International license .

\section{AFM imaging}

Atomic Force Microscopy (Nanosurf Mobile S) imaging of nanobaits was performed in air in non-contact mode. nanobait structures were diluted to $1 \mathrm{ng} / \mu \mathrm{L}$ in $1 \mathrm{mM} \mathrm{MgCl}_{2}$ and $10 \mu \mathrm{L}$ was added to freshly cleaved mica, incubated for $1 \mathrm{~min}$, rinsed with filtered Milli-Q $\mathrm{H}_{2} \mathrm{O}$, and then blow-dried with nitrogen. Prior to scanning, the mica plate was affixed to the AFM sample stage using double-sided adhesive tape. Image visualization and analysis were performed using Gwyddion.

\section{Statistical analysis}

99.9\% confidence intervals for the displacement efficiencies were calculated for all measurements. The statistical significance between two sites without and with the target was tested using a student's T-test.

\section{Results and Discussion}

Single-molecule detection of target RNAs with nanobait and nanopore sensing

We developed a workflow for nanobait detection of target RNA, ranging from patient swabbing, nucleic acid extraction, and programmable RNase $\mathrm{H}$ cutting of viral RNA (Figure 1). The RNA targets are selected by guide oligonucleotides (single-stranded DNA, $20 \mathrm{nt}$ ) that were designed to bind upstream and downstream on the specific regions in a viral genome. Then, RNase H was used to digest the RNA sequence in RNA: DNA hybrids (DNA guide oligo hybridized to viral RNA segment) and release the middle target RNA (Figure 1a, right).

Released RNA targets were identified using sequence specific binding to the nanobait (Figure 1b-c). The nanobait was designed (more details in Supplementary Figure S1) with five binding sites that could incorporate up to five targets. Nanobait was assembled by mixing a single-stranded DNA scaffold (linearized M13mp18, 7228 nt long) ${ }^{18}$ with a collection of short complementary oligonucleotides (Figure $1 \mathrm{~b}$ and Supplementary Table S2). Towards one end of the nanobait, the sensing region was designed to 
contain equally spaced sites a-e flanked by two reference structures R1 and R2, which consisted of six DNA dumbbells each (oligonucleotides are listed in Supplementary Table S3). The sensing site contained a DNA overhang, which was fully complementary to the respective target sequence. We additionally exploited a blocking oligo with a label (monovalent streptavidin or DNA flower; Supplementary Figure S2 and Table S1) that was only partially hybridized and left six bases unpaired. Assembly of the nanobait was confirmed by AFM imaging and an electrophoretic mobility shift assay (EMSA) (Supplementary Figures S3-S4 and Figure S5, respectively). Ultimately, if the target was present, it would bind to the six unpaired bases and displace the blocking oligo with the label at its complementary overhang, which is known as toehold-mediated strand displacement ${ }^{21}$. Hence, the presence of the predefined targets was indicated by the absence of a label at the respective site (Figure 1c and Figure 1d).

We determined the structure of each nanobait and ability to detect the presence or absence of targets by a single-molecule readout technique exploiting nanopore resistive-pulse sensing (Figure 1e-g). Nanopore DNA sensing works via voltage-driven translocation of negatively charged nanobaits through a small orifice towards a positively charged electrode in an electrolyte solution (Figure 1e) $)^{22}$. Here, the nanobait translocation induces a unique current blockage signature (Figure 1f). The first current drop corresponded with double-stranded DNA nanobait $\left(\Delta \mathrm{I}_{\mathrm{DNA}}\right)$. The second current drop $\left(\Delta \mathrm{I}_{\text {label }}\right)$ indicated the presence of the reference 'R1, R2' and labels 'a-e' (Figure 1c). Figure 1f depicts an exemplar nanobait nanopore event with seven downward spikes, where each spike corresponds with the matching color site on the schematic representation in Figure 1c. After strand displacement with all five targets present (a'-e', Figure 1d), the five labeled oligos were displaced and only the reference spikes remain (Figure 1g). The short duplexes were significantly smaller than the labels and not detected with these nanopores ${ }^{18}$. Each ionic current event on a single nanobait revealed the presence of multiple short RNA targets. The flexibility of the nanobait design permitted us to identify targets originating from multiple parts of the same virus or from multiple viral genomes. 
medRxiv preprint doi: https://doi.org/10.1101/2021.11.05.21265890; this version posted November 10, 2021. The copyright holder for this preprint (which was not certified by peer review) is the author/funder, who has granted medRxiv a license to display the preprint in perpetuity.

It is made available under a CC-BY-NC-ND 4.0 International license .

a Target RNA extraction

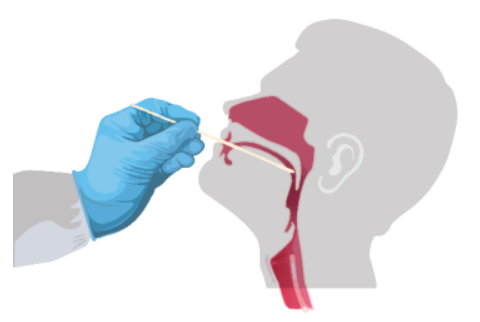

Patient sample collection

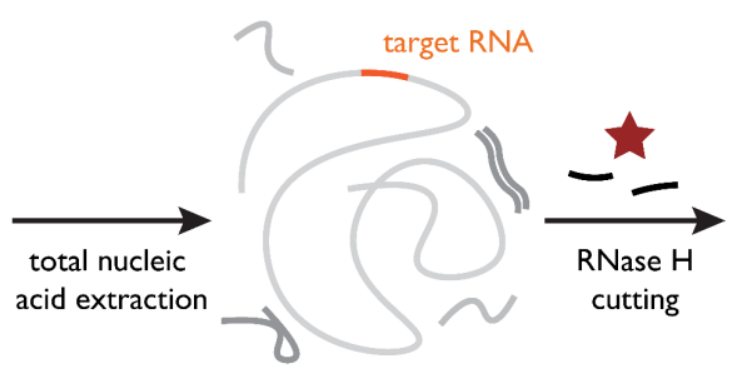

viral RNA

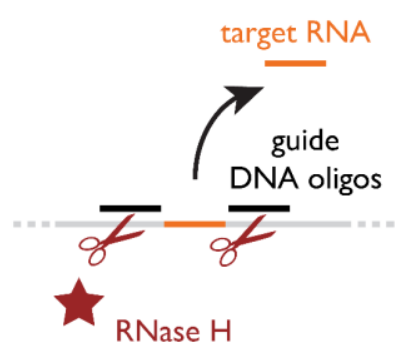

release of target RNA

b DNA nanobait preparation

single-stranded DNA scaffold

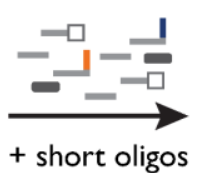

c Before strand displacement

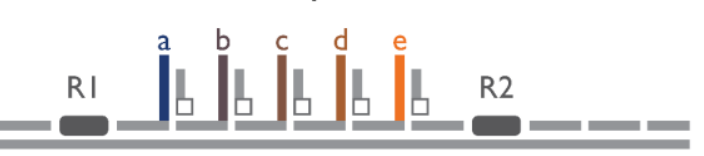

e Single-molecule nanopore readout
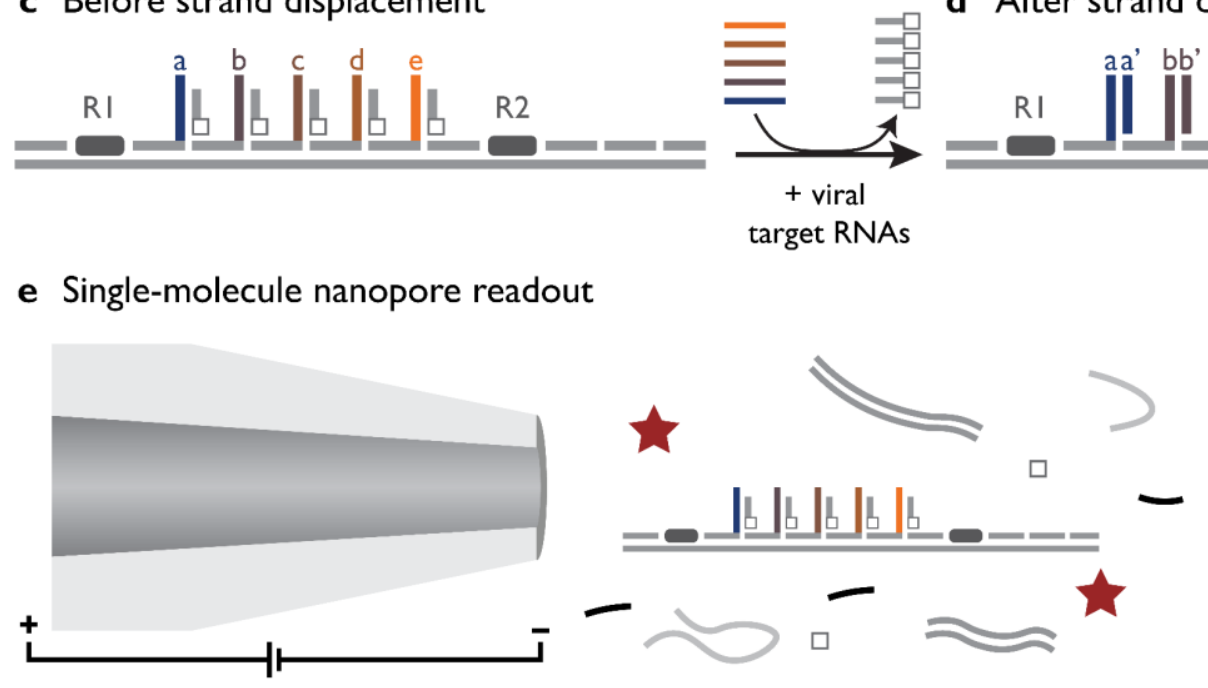

+ viral

target RNAs d After strand displacement
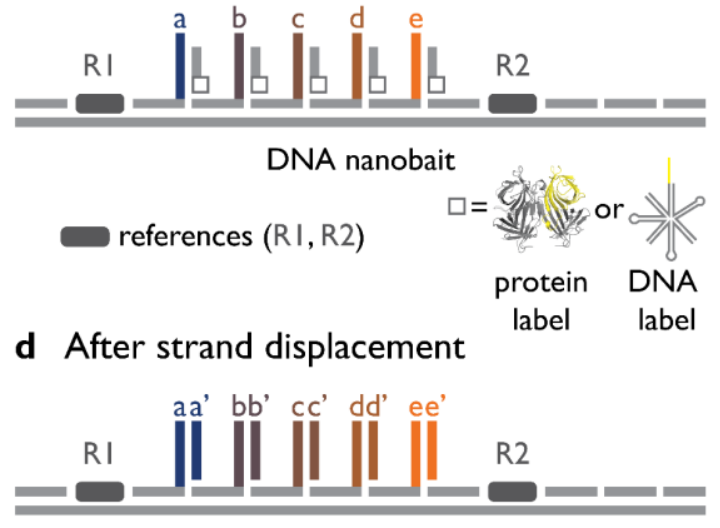

RI f Nanobait event before displacement

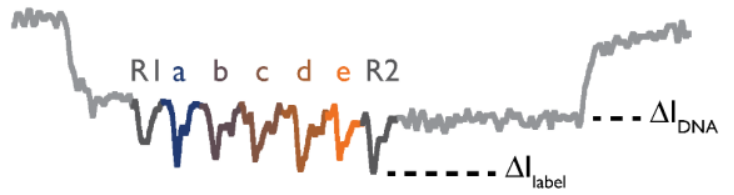

g Nanobait event after displacement

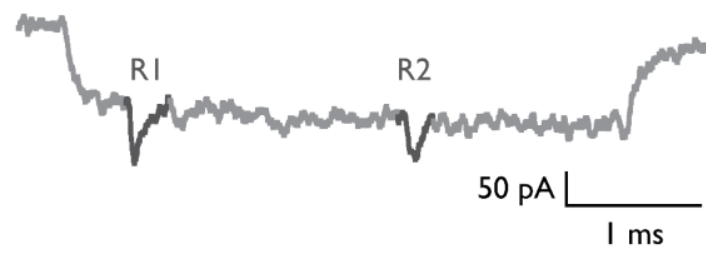

Figure 1. Self-assembled DNA nanobait strategy for multiplexed viral diagnostics.

a) Oropharyngeal swab sample is collected from patients suspected to have COVID-19. Total nucleic acids were extracted (human RNA and DNA are shown in dark gray), and target RNA was cleaved out 
medRxiv preprint doi: https://doi.org/10.1101/2021.11.05.21265890; this version posted November 10, 2021. The copyright holder for this preprint (which was not certified by peer review) is the author/funder, who has granted medRxiv a license to display the preprint in perpetuity.

It is made available under a CC-BY-NC-ND 4.0 International license .

using programmable RNase H cutting. Such treated sample was further tested for viral presence. b) Nanobait is made by mixing a single-stranded DNA scaffold (M13mp18 DNA) with short oligonucleotides where some of them carry complementary capture strands (a-e) for specific targets (a'e') in a target viral RNA. In addition, a partially complementary oligo with a structural label (protein or DNA-based, white square) is added for each site to amplify the signal in nanopore recordings. We marked a sensing region with two references (dark gray). Nanobait before c) and after d) strand displacement reactions of five targets (colored strands). If targets are present the five gray strands with labels are displaced. Two outer signals originate from reference structures that indicate the sensing region, and the five binding sites between the references are specific for the five different targets. e) Each nanobait is voltage-driven through the nanopore and detected in a complex mixture of molecules. f) Typical nanopore current signature as a function of time for a nanobait as designed with five labels present. The first current drop corresponds to DNA $\left(\Delta \mathrm{I}_{\mathrm{DNA}}\right)$ and the second to labels $\left(\Delta \mathrm{I}_{\mathrm{label}}\right)$. g) Typical nanobait event after strand displacement of all five targets. The presence of the targets is detected by the missing downward signals specific to each target.

Simultaneous identification of targets specific to multiple respiratory viruses and SARS-CoV-2 singlenucleotide variants

We designed nanobait for the multiplexed target identification of SARS-CoV-2, RSV (universal for group A), rhinovirus (universal), influenza (universal for group A), and parainfluenza 1 (Supporting information Table S4-S7). A schematical design of the nanobait for multiple respiratory viral nucleic acid targets is shown in Figure 2a. RSV is provided as an example of site-specific displacement (Figure 2a). The five targets, as well as the control (no target), were detected independently using the same nanobait. The first nanopore translocation events of the nanobait in each of the individual samples are depicted in Figure $2 \mathrm{a}$ and Supplementary Figure S6. Nanopore events with seven spikes indicated the absence of targets. If the respective target for SARS-CoV-2, RSV, rhinovirus, influenza, or parainfluenza were present, that spike 
medRxiv preprint doi: https://doi.org/10.1101/2021.11.05.21265890; this version posted November 10, 2021. The copyright holder for this preprint (which was not certified by peer review) is the author/funder, who has granted medRxiv a license to display the preprint in perpetuity.

It is made available under a CC-BY-NC-ND 4.0 International license .

was absent in the nanobait translocation event (presence of the targets are shown in Supplementary Table S4). The displacement efficiency was calculated as the difference between a no target control and the measurement for each site (fifty nanobait events for each of three nanopore recordings) $(p<0.001$; student's T test). (Figure 2c). We tested two different scenarios, with and without targets for statistical significance.

Variant discrimination with single-nucleotide resolution is an essential feature for variant diagnostics. We tested the potential of nanobait for single nucleotide variant (SNV) discrimination, by distinguishing nucleic acids from several SARS-CoV-2 variants. The five sites of nanobait allowed for the simultaneous detection of wild-type virus and four variants (sequences are listed in Table 8-12, and design principles are elaborated in the Supporting information section S7) ${ }^{23}$. The first site was wild-type SARS-CoV-2 isolated in Wuhan (B by PANGOLIN nomenclature) ${ }^{23}$. The alternative four targets were European strain B.1 and three variants of concern: ${ }^{14}$ B.1.1.7 (alpha), B.1.351 (beta), and B.1.617 (delta) that were first detected in the United Kingdom, South Africa, and India, respectively. As an example, we highlight the identification of the B.1.1.7 variant (Figure 2b). We selected a variant-specific target that was fully complementary to the capture strand on the nanobait, while the wild type (WT) target contained a mismatch in the toehold end (Supplementary Table S11). The displacement efficiency is dependent on the number and position of mismatches in the toehold domain ${ }^{24}$. Programming nanobait with a singlenucleotide mismatch allowed us to discriminate the SARS-CoV-2 variant from the WT sequence. We depict example events for each sample where all spikes are present (no targets) or the respective spike is absent depending on which variant is present (Figure 2b; more events are shown in Supplementary Figure S7; presence of the targets are shown in Supplementary Table S8). Figure 2d shows the displacement efficiency for WT targets and their corresponding variant targets for the first fifty nanobait events (colored bars). We observed a significant difference for all four variants when compared to the respective WT samples (light and dark-colored bars). 

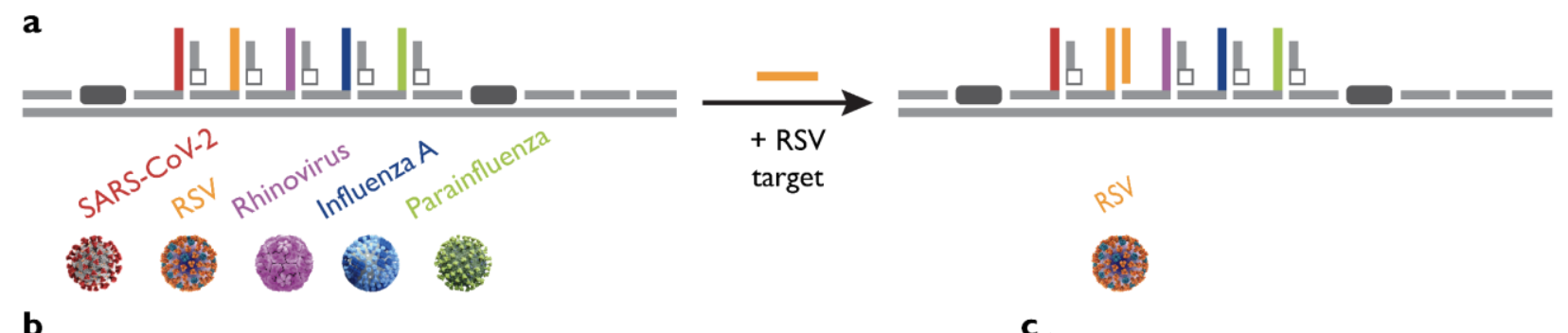

b
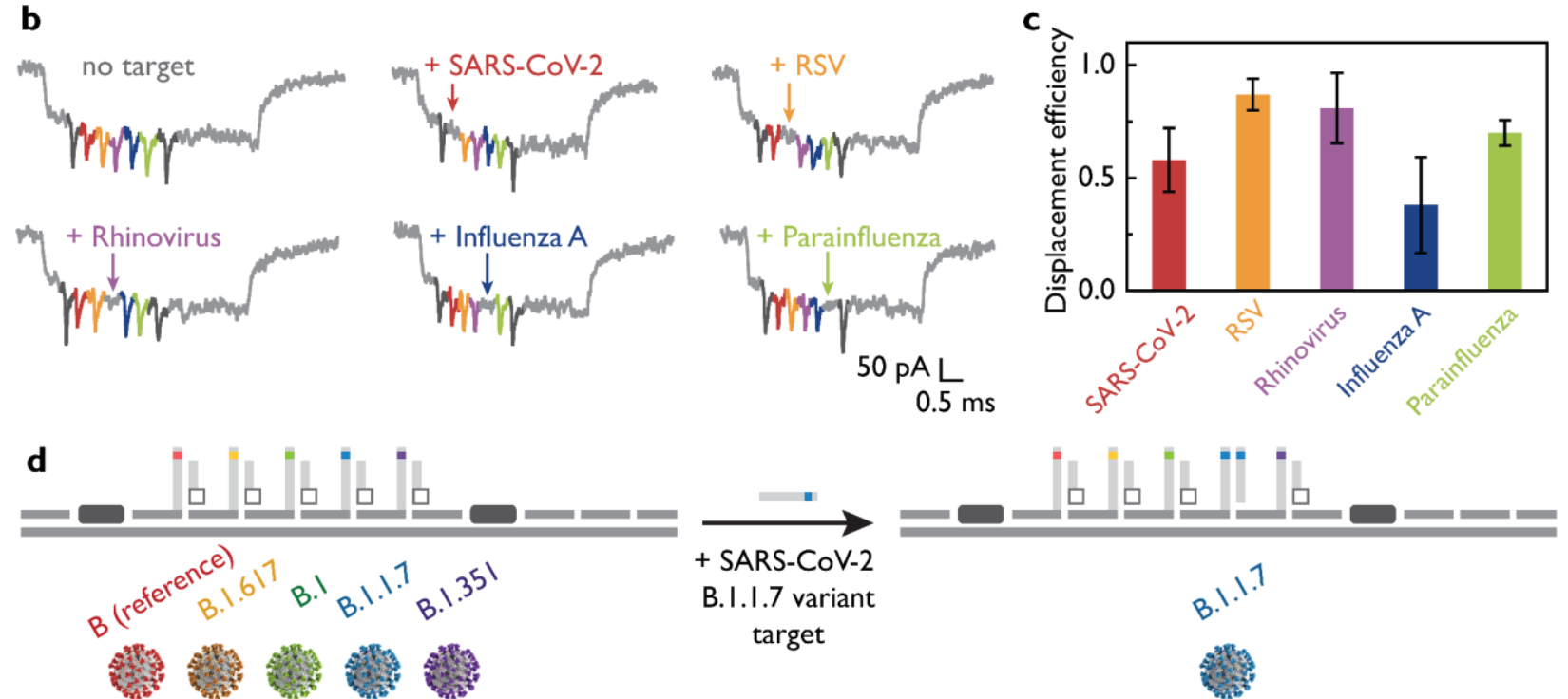

.
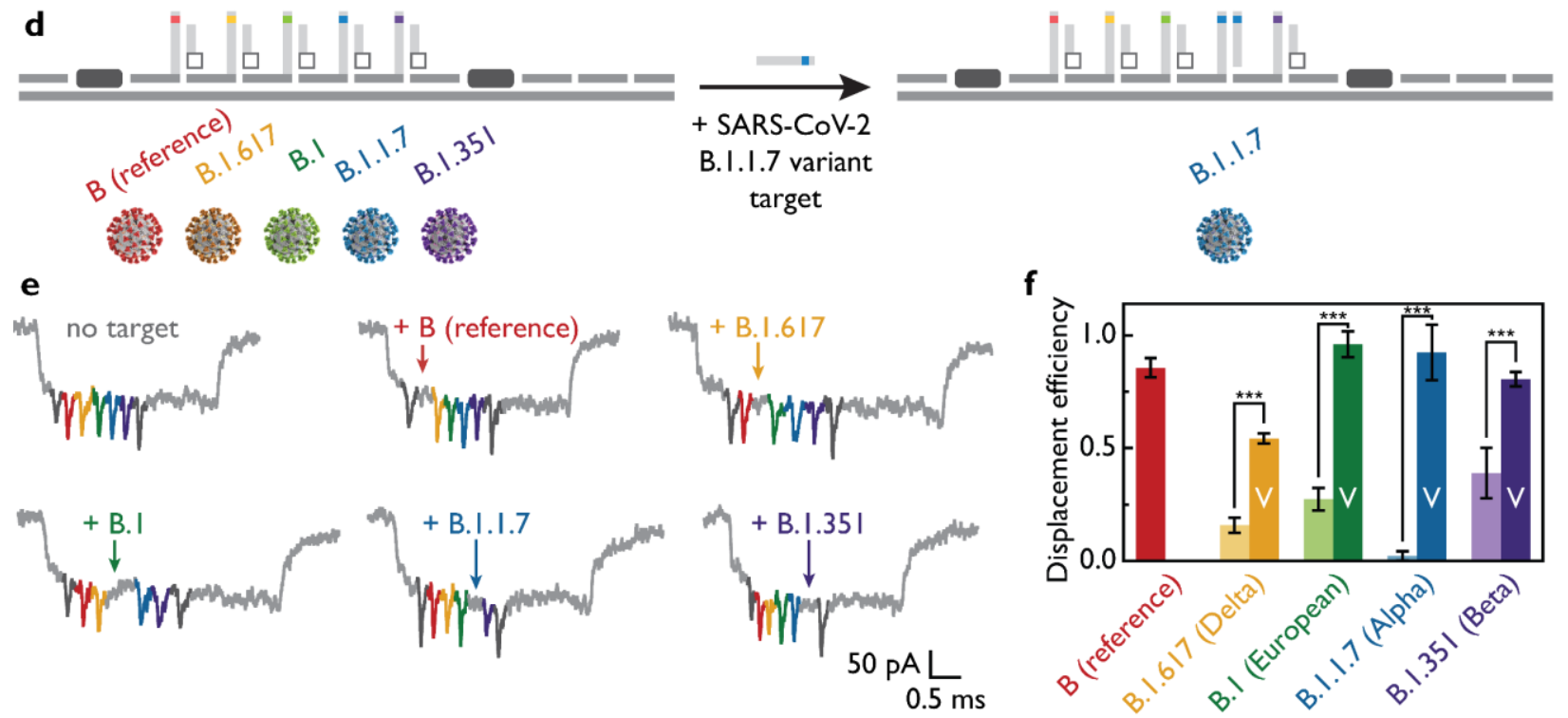

$0.5 \mathrm{~ms}$

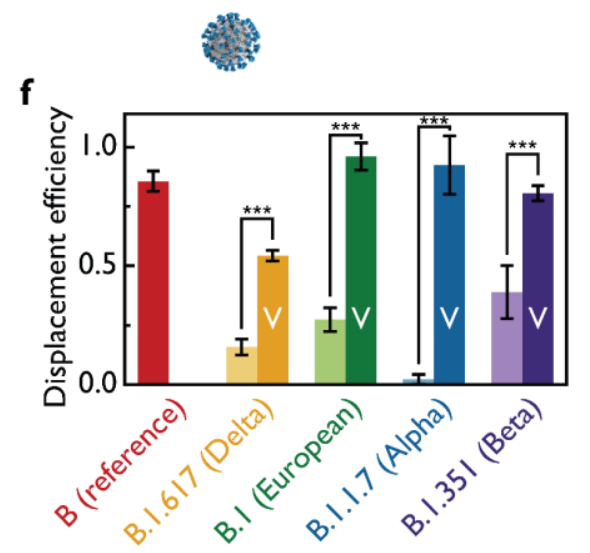

Figure 2. Multiplexed discrimination of viruses and SARS-CoV-2 variants with nanobait.

a) Nanobait is designed to have five sites specific to SARS-CoV-2, RSV, rhinovirus, influenza A, and parainfluenza. Example events for the condition without any targets and for each virus-specific target are depicted in b). The absence of the colored spike indicates the presence of each respective target. c) Displacement efficiency indicates presence of corresponding viral target. The displacement efficiency represents a measurement with target subtracted from the control (no targets). Error bars represent standard error for three nanopore measurements and fifty nanopore events per measurement. d) Nanobait 
medRxiv preprint doi: https://doi.org/10.1101/2021.11.05.21265890; this version posted November 10, 2021. The copyright holder for this preprint (which was not certified by peer review) is the author/funder, who has granted medRxiv a license to display the preprint in perpetuity.

It is made available under a CC-BY-NC-ND 4.0 International license .

designed to detect four single-nucleotide SARS-CoV-2 variants by adaptation of the target sequences. e) Example events for the condition without any targets and for each variant-specific target are depicted. The absence of the colored spike indicates the presence of each respective variant. f) Displacement efficiencies for single-nucleotide variants (labelled as ' $V$ ') are compared with the displacement efficiency for the wild-type Wuhan strain of the SARS-CoV-2 virus. Error bars represent standard error for three nanopore measurements and fifty nanopore events per measurement. The difference between conditions without and with variant targets is statistically significant ( $p<0.001$; student's T test; $N=150)$.

The identification of multiple targets for SARS-CoV-2 in a complex human transcriptome mixture

Diagnostic tests for viral RNA rely on multistep reactions and subsequent purification steps. We aimed to use nanobait for direct target identification without preamplification and purification. Here, we used nanobait for specific single-molecule detection in a complex human transcriptome mixture i.e. human total universal RNA (htRNA; Invitrogen). These nanobait could identify multiple samples from pooled samples in complex backgrounds by nanopore sensing (Figure 3a).

We pooled five synthesized SARS-CoV-2 RNA targets together to investigate the specificity and potential crosstalk between nanobait and non-specific htRNA background. After the targets were added, all sites were displaced and correctly identified using the nanopore measurements (Figure 3b). A typical current trace indicates that nanobait spikes can be easily distinguished (red boxes, Figure 3c) from nonspecific current blockages originating from the htRNA. Figures $3 \mathrm{~d}$ and $3 \mathrm{e}$ show the first five linear nanobait events for samples with and without targets and in the presence of htRNA; the displacement efficiency for all five targets is depicted in Figure 3f. Target 4 had the lowest displacement efficiency, which was in agreement with a low predicted GC content of $25 \%{ }^{25}$. Nanobait based strand displacement can operate effectively even in a complex background of htRNA, oligonucleotides, and proteins. We studied the kinetic details for both RNA and DNA targets and determined that 10 minutes was the optimal 
medRxiv preprint doi: https://doi.org/10.1101/2021.11.05.21265890; this version posted November 10, 2021. The copyright holder for this preprint (which was not certified by peer review) is the author/funder, who has granted medRxiv a license to display the preprint in perpetuity.

It is made available under a CC-BY-NC-ND 4.0 International license .

incubation time for the strand displacement reaction (corresponding plots and events are presented in Supplementary section S8; presence of the targets are shown in Supplementary Table S13; target sequences and oligonucleotides are listed in Tables S14-S16).

$\mathbf{a}$ synthesized SARS-CoV-2 RNA

Sample I Sample 2 Sample 3 Sample 4 Sample 5
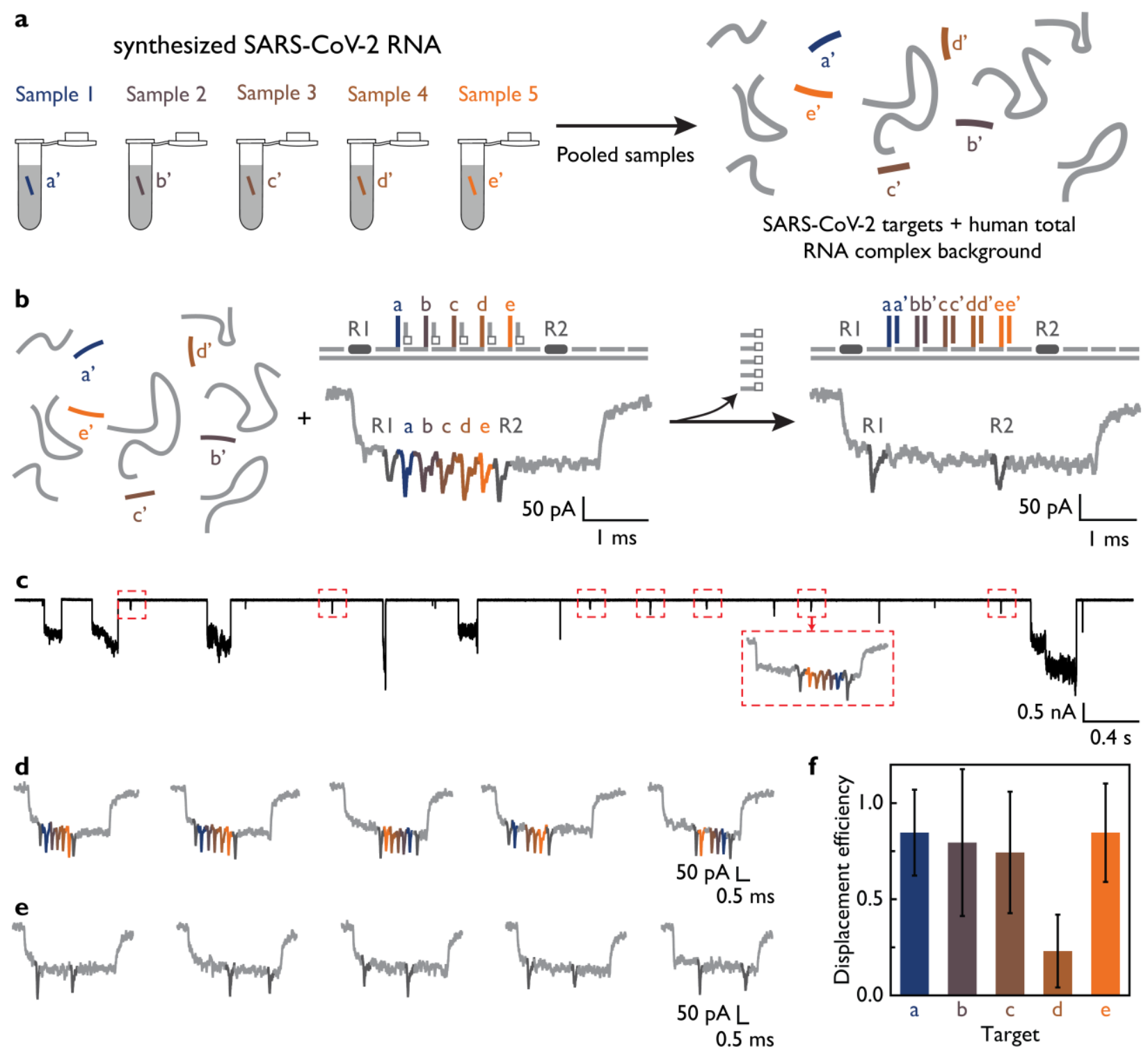

Figure 3. Nanobait detects multiple synthesized SARS-CoV-2 RNA targets in the background of the human transcriptional RNA.

a) Five targets from different regions in a viral genome can be separately targeted and pooled for nanopore analysis. Five targets are mixed with intact human total RNA in the background, to verify that viral RNA purification is not a required step. b) After the addition of nanobait to a mix, all five targets can 
medRxiv preprint doi: https://doi.org/10.1101/2021.11.05.21265890; this version posted November 10, 2021. The copyright holder for this

It is made available under a CC-BY-NC-ND 4.0 International license .

be identified in parallel as shown in the example events. c) Ionic current traces indicate the specificity of the method for the identification of nanobait-specific events even in a complex background where large downward signals originate from background including long RNAs. All nanobait events have been highlighted in red dashed boxes. d) First five single-file nanobait events for sample mixed with only human total RNA indicate correct current signature. e) The first five single-file nanobait events that have been previously mixed with targets and human total RNA. All targets are present since corresponding spikes are absent in nanopore events. f) Displacement efficiency calculated for the sample with targets added (nanobait with targets and human total RNA) for all five sites. Error bars represent standard error for three nanopore measurements and fifty nanopore events per measurement.

\section{Design of target sites depends on viral RNA secondary structure}

We next aimed to optimize multiple parameters in designing an efficient target RNA identification system. One key parameter was the successful excision of the short RNA targets from viral RNA. We found that the location of the target RNA in the viral RNA secondary structure affected the concentration of free target RNA and consequently affected displacement efficiency. A target in a highly complementary region would remain bound to the viral RNA after cutting and prevent detection. In contrast, the release of the target after RNase H excision increases when more unpaired bases were in the target region than within the secondary structure of the viral RNA. For future experiments, we maximized the number of unpaired bases to increase the effective concentration of the target in solution and consequently aid detection.

The role of unpaired bases was demonstrated by the detection of three targets in $\sim 3.6 \mathrm{~kb}$ RNA genome of MS2 virus (Figure 4a, the minimal free energy secondary structure ${ }^{26}$ ). The three targets (T1, T2, and T3) had a decreasing percentage of unpaired bases (T1 - 55\%, T2 - 30\%, and T3 - 25\%). Subsequently, we designed oligos and employed RNase $\mathrm{H}$ cutting of all three targets and quantified the displacement 
efficiency using nanobait with the three sites (Figure 4b, more events are shown in Supplementary Figure S14; presence of the targets are shown in Supplementary Table S17; oligonucleotides are listed in Supplementary Tables S18-S22). Efficient cutting of viral RNA was confirmed by agarose gel electrophoresis (Supplementary Figure S10). For each target, the original 3.6 kb RNA was cut in fragments of the predicted length; additionally, the predicted fragment lengths were comparable when all three targets were cut simultaneously. We confirmed that target T1 was free in solution by hybridizing it to the complementary capture strand $\mathrm{C}$ and detected it using polyacrylamide gel electrophoresis (PAGE) (Figure 4c). After cutting, target T2 was not visible by PAGE (Supplementary Figure S13), and the oligonucleotides running speed and non-specific interactions were validated on a control PAGE (Supplementary Figure S11 and S12).

Example nanopore events and displacement efficiency with and without targets released from the MS2 RNA genome after RNase $\mathrm{H}$ cutting are shown in Figures $4 \mathrm{~b}$ and $4 \mathrm{~d}$. The plot indicates that displacement was detected for all three targets. Target T1 had the highest displacement efficiency, while target T3 had the lowest displacement efficiency. As predicted, displacement efficiency (Figure 4d) correlated with unpaired base percentage in the RNA structure for each target, signifying an important design principle in selecting viral target regions for detection. 
a
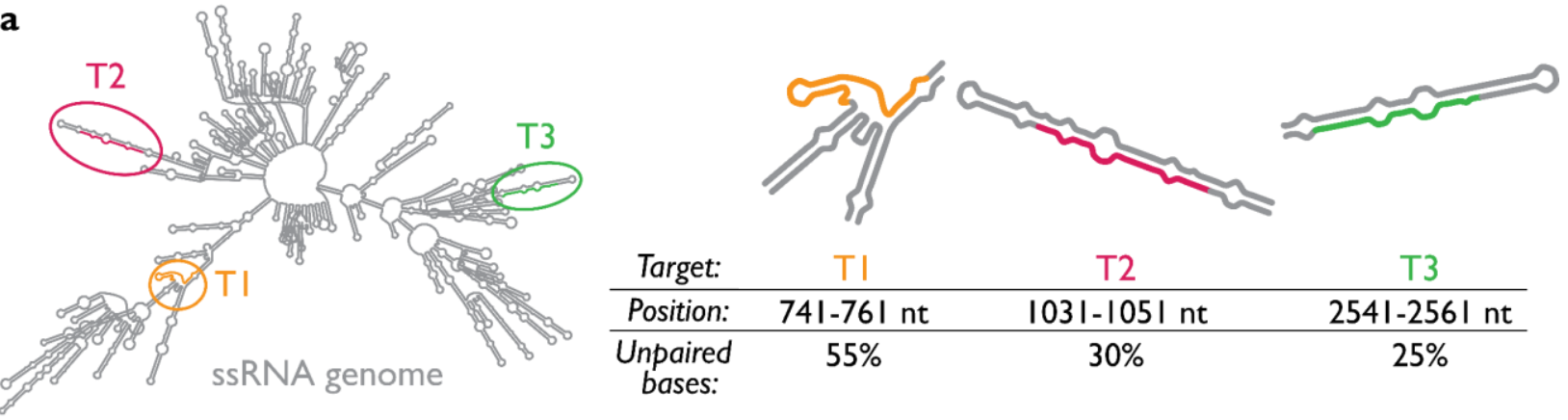

b
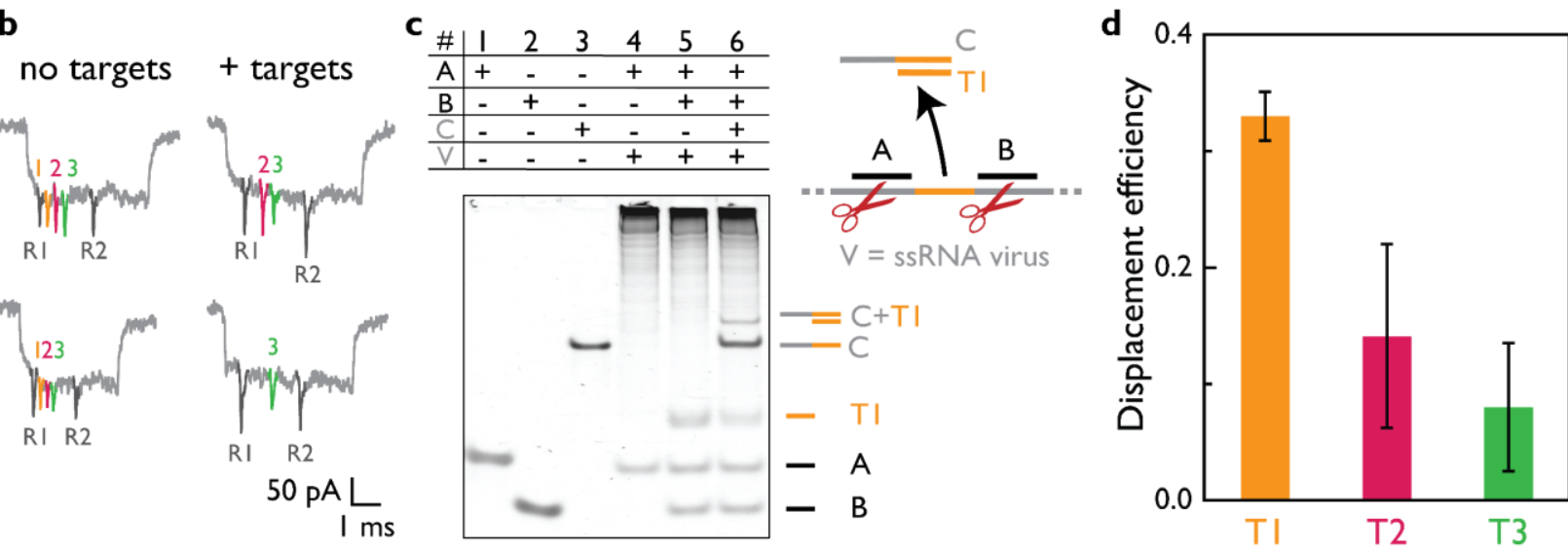

Figure 4. Position of a target in a viral RNA secondary structure influences the efficiency of target identification.

a) We demonstrated that the position of a target in a viral RNA correlates with the efficiency of release of the target after RNase H cutting. MS2 viral RNA is presented as the minimal free energy structure. Three targets (T1, T2, T3) are selected to have a different level of paired bases for a constant $20 \mathrm{nt}$ long target. For each target, a region in MS2 viral RNA is indicated with the percentage of unpaired bases in each target. b) Nanobait events with three targets present are shown, indicating the correct design (no targets). Events for the sample where cut long RNA is mixed with nanobait show displacement (+ targets). Each spike color corresponds to a site on nanobait. c) EMSA shows guide oligos A and B (lane 1 and 2, respectively), and complementary oligo $\mathrm{C}$ to target $\mathrm{T} 1$ (lane 3). If only guide oligo A is used for viral RNA cutting (lane 4), there is only the oligo A band and the high molecular weight cut viral RNA. Once both guide oligos are added, an additional band originating from released target T1 RNA emerges (lane 5). Once strand $\mathrm{C}$ is added to the same sample, we can see its shift after T1 binding (lane 6). d) 
medRxiv preprint doi: https://doi.org/10.1101/2021.11.05.21265890; this version posted November 10, 2021. The copyright holder for this preprint (which was not certified by peer review) is the author/funder, who has granted medRxiv a license to display the preprint in perpetuity.

It is made available under a CC-BY-NC-ND 4.0 International license .

Displacement efficiency of target RNAs correlates with the percentage of unpaired bases in a target. T1 has shown the highest displacement while T2 and T3 have lower displacement efficiencies. Error bars represent standard error for three nanopore measurements and fifty nanopore events per measurement.

Specific identification of SARS-CoV-2 RNA targets in clinical oropharyngeal swabs without prior amplification

After establishing that RNase H had cut the MS2 RNA, we considered that nanobait could detect SARSCoV-2 RNA in clinical samples. We accessed oropharyngeal swabs from patients suspected to have COVID-19; the viral load SARS-CoV-2 in oropharyngeal swabs in the clinical phase is $10^{8}-10^{11}$ $\operatorname{copies}^{27}$. We used nanobait in nucleic acid extractions from clinical samples that had been prepared for qRT-PCR (more details in Supplementary section S11; oligos are listed in Supplementary Tables S23$\mathrm{S} 26)^{15}$. SARS-CoV-2 targets (S1, S2, and S3) were designed in conserved regions of the genome that contained the highest percentage of unpaired bases (Figure 5a). S1 was in the region encoding the spike (S) protein, S2 was in the region encoding the small envelope (E) glycoprotein, and S3 was in the nucleocapsid $(\mathrm{N})$ protein-coding region. Total nucleic acids from clinical samples were subjected to our RNase $\mathrm{H}$ protocol (Figure 5b) and then mixed with a nanobait with sensing sites S1, S2, and S3. The reaction did not require further purification or preamplification before the nanopore readout. The nanobait mixture was then analyzed with nanopores containing the complex background of DNA (human and optionally DNA flower), long RNAs (human and potentially viral), short guide oligos, and proteins (RNase $\mathrm{H}$ and monovalent streptavidin).

Nanopore events from the nanobait mixed with RNase $\mathrm{H}$ treated negative patient samples (confirmed with qRT-PCR) are shown in Figure 5c. In addition to the two reference spikes (dark gray), three further spikes were visible and corresponded with sites for S1 (blue), S2 (green), and S3 (orange). As shown above, the nanobait current signature was not affected by the complex background or unspecific binding of DNA guide oligos. The missing spike associated with specific displacement was apparent when the nanobait 
was mixed with the SARS-CoV-2 positive swab sample as confirmed by qRT-PCR (Figure 5d). We repeated the procedure on a further ten occasions with qRT-PCR-confirmed SARS-CoV-2 positive and negative clinical samples. The nanobait displacement efficiencies for negative and positive samples were consistent with the qRT-PCR results (Figure 5e).

We additionally exploited a DNA flower as an alternative to a monovalent streptavidin. We observed comparable results with this DNA-based system (more details in Supplementary section S12), indicating that the detection system can be based only on DNA. An all-DNA nanobait system may aid future upscaling.

Our nanobait approach bypasses pre-amplification and purification and hence avoids these potentially time-consuming and expensive steps. Furthermore, the nanopore readout time can be further reduced by performing real-time analysis on the QuipuNet convolutional neural network ${ }^{20}$. QuipuNet has high accuracy with an analysis speed of 1,600 events/s, which is more than sufficient for rapid viral detection ( 10 $\mathrm{min})$. 
medRxiv preprint doi: https://doi.org/10.1101/2021.11.05.21265890; this version posted November 10, 2021. The copyright holder for this preprint (which was not certified by peer review) is the author/funder, who has granted medRxiv a license to display the preprint in perpetuity.

It is made available under a CC-BY-NC-ND 4.0 International license .

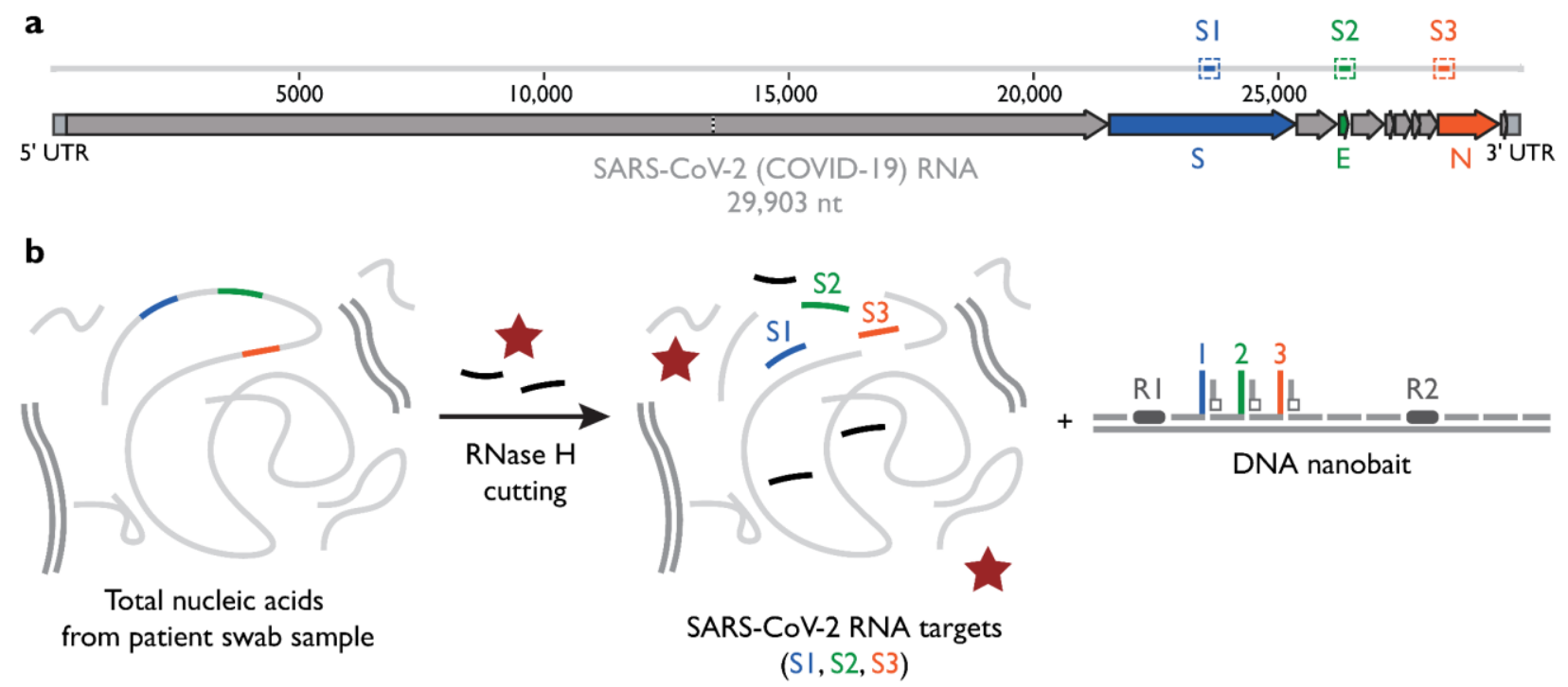

c Negative patient sample
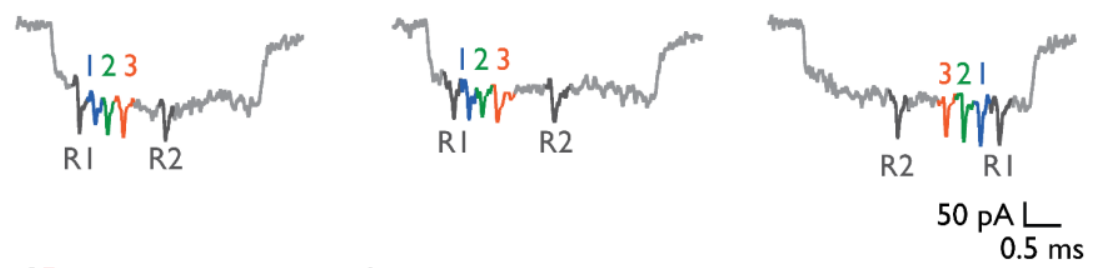

dPositive patient sample
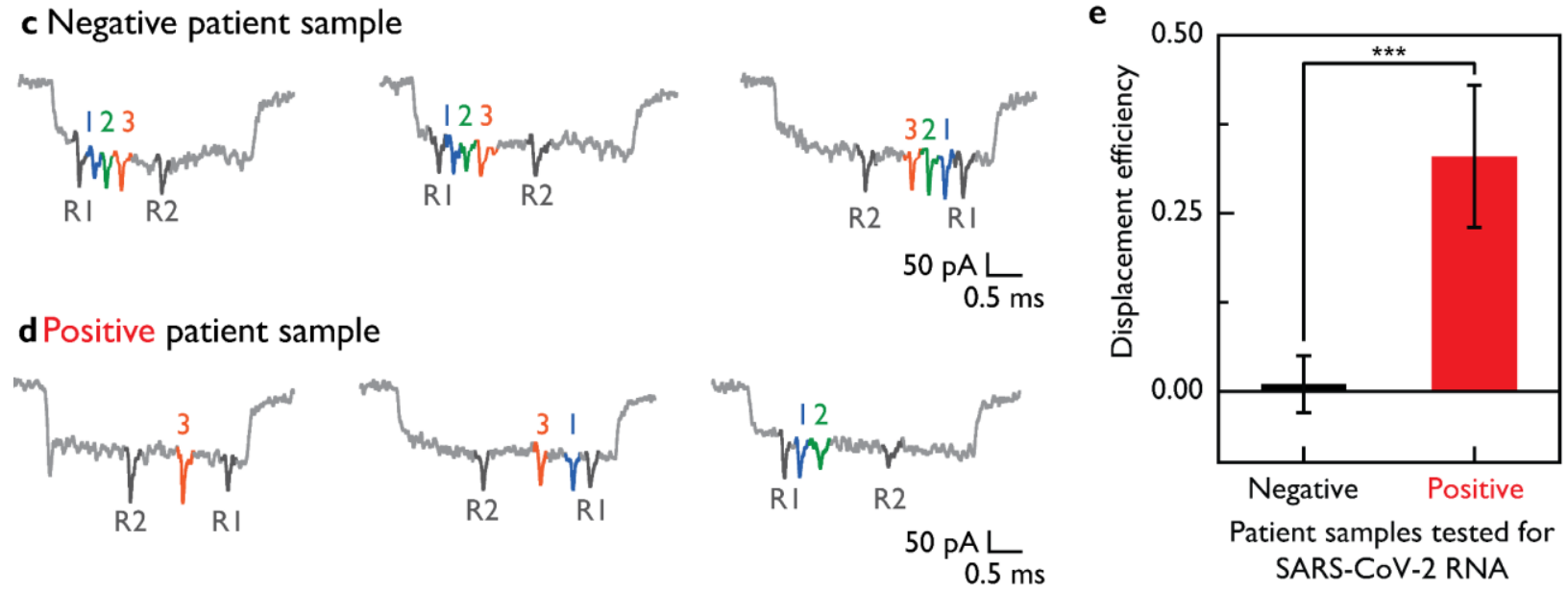

Figure 5. SARS-CoV-2 detection in patient oropharyngeal swab samples.

a) We designed three targets (S1, S2, S3) in conserved regions that code for spike (S), envelope (E), and nucleocapsid $(\mathrm{N})$ proteins as indicated in the schematic representation of the SARS-CoV-2 RNA genome (29,903 nt long). b) Total nucleic acids from oropharyngeal swabs contain a mix of human DNA and RNA that either have tested positive or negative for the COVID-19 with RT-qPCR. The next step included RNase $\mathrm{H}$ target release from long RNA and mixing with nanobait. If targets are present, they displace the oligo harboring a label. In this way, the displacement efficiency for each site is detectable with nanopores. Real-time analysis in a complex mixture of various biomacromolecules (human DNA, human RNA, RNase H, streptavidin, guide oligos) is performed directly without prior purification 
enabling rapid nanopore readout ( $10 \mathrm{~min})$. Example events for both negative and positive SARS-CoV-2 samples were presented in c) and d), respectively. e) The displacement efficiency in a negative sample differs from positive samples for ten repeats. Error bars indicate standard error for all events in the first ten minutes. Difference between negative and positive samples has statistical significance $(\mathrm{p}<0.001$; student's T test).

Here, we demonstrate the site-specific excision of a target from long viral RNA using RNase H cutting. In this way, we increase the displacement efficiency by ensuring the exact target sequence for displacement reaction in comparison to non-specific RNA fragmentation ${ }^{28}$. Additionally, site-specific RNA cutting can be achieved using DNAzymes or even CRISPR/Cas system ${ }^{29,30}$.

Previous nanopore studies have demonstrated the ability to detect one or a limited number of short nucleic acid species in isolated form ${ }^{10,12,28,31-33}$. However, the real challenge is the biological complexity within a test sample and discriminating targets in this complex background ${ }^{11,34}$. Our work demonstrates that DNA nanotechnology can be used to detect specific targets in complex clinical samples with nanopores. As a proof of concept, we tested nanobait against five different respiratory viruses or SARS-CoV-2 variants in parallel. Previously, we showed that with DNA encoding a library of $2^{112}$ molecules with the potential to test for 100 s and 1000 s of viral targets in parallel can be created ${ }^{18,35}$, especially when multiplexed nanopore systems become more advanced.

Recent studies have developed a viral nucleic acid detection system using nanopores which holds great promise for a rapid detection system ${ }^{10,12,13,36}$. However, preamplification and enzymatic steps in preparation for nanopore detection limit the utility of such methods. Our nanobait system does not necessitate preamplification and can identify native RNA sequences without the need for sequencing. The design of this approach overcomes an issue of non-specific spikes in nanopore measurements by using the absence of a downward spike as a positive signal for identification of the presence of the target sequence. 
medRxiv preprint doi: https://doi.org/10.1101/2021.11.05.21265890; this version posted November 10, 2021. The copyright holder for this preprint (which was not certified by peer review) is the author/funder, who has granted medRxiv a license to display the preprint in perpetuity.

It is made available under a CC-BY-NC-ND 4.0 International license .

Nanobait can also identify multiple targets from the same viral RNA, hence offering enhanced specificity and accuracy for viral identification, as we demonstrated for the detection of SARS-CoV-2 in clinical specimens.

Rapid programmability of diagnostic platforms is of paramount importance for detecting new viruses or their variants as they arise ${ }^{14}$. Our nanobait is rapidly adaptable for new viral targets, as we demonstrated by discriminating the emerging SARS-CoV-2 variants. Our study has the potential for amplification-free native RNA identification. Nanobait bypasses amplification sequence biases by detecting innate RNA diversity. Our results show that nanobait identify short and long RNAs and may find wider applications in analysis of physiological and pathological conditions including cancer detection.

In conclusion, we have demonstrated the simultaneous identification of nucleic acids from multiple viruses and SARS-CoV-2 variants in a specific and rapid approach by combining DNA nanotechnology and nanopore sensing. We employed the easily programmable nanobait with strand displacement for the discrimination of SARS-CoV-2 WT RNA from variant RNA, including three variants of epidemiological concern $^{14}$. Finally, we successfully used the nanobait-based nanopore sensing method in clinical samples and could accurately discriminate SARS-CoV-2 negative from positive patient swabs with $\sim 10$ min nanopore readout. Nanobait avoids reverse transcription, amplification, or reaction purification, therefore, bypassing enzymatic biases and some additional steps. As nanobait has proven to be specific and accurate for viral detection in patient samples, we think our platform can be employed for native RNA detection. Nanobait paves a way for a multiplexed amplification-free RNA detection method that is dependent only on the rapid single-molecule readout of nanobait structure. 


\section{References}

1. Caliendo, A. M. et al. Better tests, better care: improved diagnostics for infectious diseases. Clinical infectious diseases : an official publication of the Infectious Diseases Society of America 57, S139-S170 (2013).

2. Burki, T. H. The economic cost of respiratory disease in the UK. The Lancet Respiratory 5, 381 (2017).

3. Leung, N. H. L. Transmissibility and transmission of respiratory viruses. Nature Reviews Microbiology 19, 528-545 (2021).

4. Daniel, P., Bewick, T., Welham, S., Mckeever, T. M. \& Lim, W. S. Adults miscoded and misdiagnosed as having pneumonia: results from the British Thoracic Society pneumonia audit. Thorax 72, 376-379 (2017).

5. Europe, W. H. Organization. R. O. for. Methods for the detection and identification of SARS-CoV-2 variants. World Health Organization. Regional Office for Europe (2021) doi:10.1002/9781119650034.ch16.

6. Esbin, M. N. et al. Overcoming the bottleneck to widespread testing: A rapid review of nucleic acid testing approaches for COVID-19 detection. RNA 26, 771-783 (2020).

7. Caliendo, A. M. Multiplex PCR and emerging technologies for the detection of respiratory pathogens. Clinical Infectious Diseases 52, 326-330 (2011).

8. Verschueren, D. v. et al. Label-Free Optical detection of DNA translocations through plasmonic nanopores. ACS Nano 13, 61-70 (2019).

9. Ivankin, A. et al. Label-free optical detection of biomolecular translocation through nanopore arrays. ACS Nano 8, 10774-10781 (2014).

10. Stein, U. et al. Quantification of mRNA expression using single-molecule nanopore sensing. ACS Nano 14, 13964-13974 (2020).

11. Galenkamp, N. S., Soskine, M., Hermans, J., Wloka, C. \& Maglia, G. Direct electrical quantification of glucose and asparagine from bodily fluids using nanopores. Nature Communications 9, 4085 (2018).

12. Sethi, K. et al. Direct detection of conserved viral sequences and other nucleic acid motifs with solid-state nanopores. ACS Nano 15, 8474-8483 (2021).

13. Beamish, E., Tabard-Cossa, V. \& Godin, M. Programmable DNA nanoswitch sensing with solid-state nanopores. ACS Sensors 4, 2458-2464 (2019).

14. Konings, F. et al. SARS-CoV-2 Variants of Interest and Concern naming scheme conducive for global discourse. Nature Microbiology 6, 821-823 (2021). 
15. Parmar, S. et al. A blueprint for the implementation of a validated approach for the detection of SARS-Cov2 in clinical samples in academic facilities. Wellcome Open Research 5, (2020).

16. Westgard, J. O., Groth, T., Aronsson, T., Falk, H. \& de Verdier, C. H. Performance characteristics of rules for internal quality control: probabilities for false rejection and error detection. Clinical Chemistry 23, 1857-1867 (1977).

17. Wolfe, B. R., Porubsky, N. J., Zadeh, J. N., Dirks, R. M. \& Pierce, N. A. Constrained multistate sequence design for nucleic acid reaction pathway engineering. Journal of the American Chemical Society 139, 3134-3144 (2017).

18. Bell, N. A. W. \& Keyser, U. F. Digitally encoded DNA nanostructures for multiplexed, single-molecule protein sensing with nanopores. Nature Nanotechnology 11, 645-651 (2016).

19. Fairhead, M., Krndija, D., Lowe, E. D. \& Howarth, M. Plug-and-play pairing via defined divalent streptavidins. Journal of Molecular Biology 426, 199-214 (2014).

20. Misiunas, K., Ermann, N. \& Keyser, U. F. QuipuNet: Convolutional neural network for single-molecule nanopore sensing. Nano Letters 18, 4040-4045 (2018).

21. Kong, J., Zhu, J., Chen, K. \& Keyser, U. F. Specific biosensing using DNA aptamers and nanopores. Advanced Functional Materials 29, 1807555 (2019).

22. Dekker, C. Solid-state nanopores. Nature Nanotechnology 2, 209-215 (2007).

23. Rambaut, A. et al. A dynamic nomenclature proposal for SARS-CoV-2 lineages to assist genomic epidemiology. Nature Microbiology 5, 1403-1407 (2020).

24. Kong, J., Zhu, J. \& Keyser, U. F. Single molecule based SNP detection using designed DNA carriers and solid-state nanopores. Chemical Communications 53, 436-439 (2016).

25. Reynolds, A. et al. Rational siRNA design for RNA interference. Nature Biotechnology 22, 326-330 (2004).

26. Zuker, M. \& Stiegler, P. Optimal computer folding of large RNA sequences using thermodynamics and auxiliary information. Nucleic Acids Research 9, 133-148 (1981).

27. Wölfel, R. et al. Virological assessment of hospitalized patients with COVID-2019. Nature 581, 465-469 (2020).

28. Zhou, L. et al. Programmable low-cost DNA-based platform for viral RNA detection. Science Advances 6, eabc6246 (2020).

29. Wang, Y., Nguyen, K., Spitale, R. C. \& Chaput, J. C. A biologically stable DNAzyme that efficiently silences gene expression in cells. Nature Chemistry 13, 319-326 (2021).

30. O'Connell, M. R. et al. Programmable RNA recognition and cleavage by CRISPR/Cas9. Nature 516, 263-266 (2014). 
31. Cao, C. et al. Aerolysin nanopores decode digital information stored in tailored macromolecular analytes. Science Advances 6, eabc2661 (2020).

32. Wanunu, M. et al. Rapid electronic detection of probe-specific microRNAs using thin nanopore sensors. Nature Nanotechnology 5, 807-814 (2010).

33. Maglia, G., Heron, A. J., Stoddart, D., Japrung, D. \& Bayley, H. Analysis of single nucleic acid molecules with protein nanopores. Methods in enzymology 475, 591 (2010).

34. Raveendran, M., Lee, A. J., Sharma, R., Wälti, C. \& Actis, P. Rational design of DNA nanostructures for single molecule biosensing. Nature Communications 11, 4384 (2020).

35. Chen, K. et al. Digital Data Storage Using DNA nanostructures and solid-state nanopores. Nano Letters 19, 1210-1215 (2019).

36. Bošković, F. \& Keyser, U. F. Nanopore microscope identifies RNA isoforms with structural colors.

Preprint at https://www.biorxiv.org/content/10.1101/2021.10.16.464631v1.full (2021).

\section{Acknowledgments}

We thank Prof Paul Lehner for his evaluation of the project and advice on unmet diagnostic needs. We thank Tim Fitzmaurice for his operational help during the COVID-19 pandemic. We acknowledge the Statistics Clinic, Centre for Mathematical Sciences for their guidelines on a statistical analysis of data presented in this study. Funding: J.Z., K.C., and U.F.K. acknowledge funding from a European Research

Council (ERC) consolidator grant (DesignerPores No. 647144). U.F.K., S.B. and J.Z. were supported by a Wellcome Trust DCF grant. F.B. acknowledges funding from George and Lilian Schiff Foundation Studentship, the Winton Programme for the Physics of Sustainability Ph.D. Scholarship, and St John's College Benefactors' Scholarship. A.O. acknowledges funding from the Cambridge Trust Vice Chancellor's Award. R.T. acknowledges funding from the European Union's Horizon 2020 research and innovation programme under the Marie Sklodowska-Curie grant agreement No 892333, and from the Blavatnik Family Foundation. M.F.A. acknowledges funding from UKSCAB scholarship. N.E. acknowledges funding from the EPSRC, Cambridge Trust, and Trinity Hall, Cambridge. M.F. and M.H. 
medRxiv preprint doi: https://doi.org/10.1101/2021.11.05.21265890; this version posted November 10, 2021. The copyright holder for this

It is made available under a CC-BY-NC-ND 4.0 International license .

acknowledge funding from the Biotechnology and Biological Sciences Research Council (BBSRC, BB/I006303/1).

This work was supported by the NIHR Cambridge Biomedical Research Centre and NIHR AMR

Research Capital Funding Scheme [NIHR200640]. The views expressed are those of the author(s) and not necessarily those of the NIHR or the Department of Health and Social Care. S.B. is supported by a Wellcome senior research fellowship (215515/Z/19/Z). The funders had no role in the design and conduct of the study; collection, management, analysis, and interpretation of the data; preparation, review, or approval of the manuscript; and decision to submit the manuscript for publication.

\section{Author contributions}

F.B. and U.F.K. conceived the idea. F.B., J.Z., K.C., and M.F.A. prepared nanobait designs. J.Z. and F.B. designed the sequences for respective targets. F.B. performed the experiments using monovalent streptavidin. J.Z. performed the experiments using DNA flower and assembled DNA flower. A.O. performed gel electrophoresis and analyzed respective data. F.B. performed electrophoretic mobility shift assay. R.T. performed AFM imaging of nanobait. F.B., J.Z., and M.Đ. analyzed the nanopore data. J.P.D. and S.B. collected oropharyngeal patient samples, extracted nucleic acids, and performed qRT-PCR. M.F. and M.H. prepared monovalent streptavidin. F.B. and U.F.K. wrote the initial manuscript draft. F.B., J.Z., A.O. and K.C. prepared the draft manuscript. All authors contributed to the discussion and the final manuscript version.

\section{Competing interests}

U.F.K. and F.B. have filed a priority patent application for the DNA nanobait method. U.F.K., K.C. and M.A. are co-founders of Cambridge Nucleomics. Other authors do not have competing interests. 